\title{
Constitutional Law as Ethico-Political Discourse
}

\author{
Tengku Ahmad Hazri*
}

Several scholars and commentators have argued that constitutional law is "one of the most under-developed areas of fiqh." That this is so is hardly surprising: constitutional law as it has been conceived thus far developed in the context of the modern nation-state and is thus historically foreign to Islam. For the most part of history, the various caliphates, sultanates and governments which together constituted dar al-islam (territory of Islam) operated under unwritten constitutions, yet firmly under the purview of the Shari'ah, so that, according to Noah Feldman, "the arrival of written constitutionalism in the Muslim world marked the beginning of the end of the Islamic state."

Nonetheless, constitutional law is the most basic and fundamental law of any legal system today, and it is this law that defines and shapes the nation and its legal order. Not a few commentators have censured the modern nation-state as divisive and sectarian, artificially segmentising the entire Muslim world into political units which forsake the common faith that unites all believers. ${ }^{3}$ We would propose a different way of thinking about this, namely that this phenomenon represents a challenge to accomplish fraternity and to forge bonds of brotherhood even with the most rudimentary of commonalities. Indeed, in many cases the "nation" was born out of nothing more than the urgency of different communities within a given territory to repel a common aggressor or oppressor (such as imperialist or colonialist power), despite vast differences in culture, custom, language and law. Thus the ability to live up to this challenge is the litmus test for the universalism of Islam.

An Islamic constitutional law, however nascent it is, must have this backdrop in mind, while being vigilantly conscious and cognisant of the evolving nature of constitutionalism and the global society. It must also be flexible enough so that new partnerships and co-operations are not stymied by an excessive obsession with the nation-state while compromising the broader prospect towards transnational alliances. A particularly telling example is contemporary West Asian states after the Arab Spring. 
Despite having more than one commonality, such as sharing a common religion, language and culture, the Arab states were nevertheless drowned in constitutional quarrels of a domestic nature. In drafting the new constitution of Egypt, for instance, parties quibbled as to whether Shari'ah "rules" or "principles" should be the foundation of the constitution. ${ }^{4}$ When European states were devastated and wrecked economically and politically in the aftermath of the Second World War, the remedy proposed was greater European integration, beginning with the Treaty of Rome (1957) to establish a common market, i.e. the European Economic Community (EEC), the predecessor to the present European Union (EU). Yet a different scenario unfolded after the uprisings that swept the Arab world, and the Arab states are as divided as ever. Ironically, the Westphalian nation-state model which the Arab states constitutionally strive hard to accommodate has long since been transcended by the very region that produced it.

There is in fact a great prospect for a common constitutional framework for cooperation among the states in certain fields, for example, with regard to business, Islamic banking and finance, education and health care, which may all benefit from the evolving nature of constitutionalism.

Since we have understood the present constitutional challenge of the Muslim world as one of establishing ties and fraternities in all areas, it follows that the constitutional model that is adopted cannot stand in the way of such unions. The objective therefore has always to be to readjust, reconstitute and reconstruct the polity in a manner that it is favourable to the formation of such partnerships, in accordance with the needs, aspirations and resources of the people. Such an objective naturally falls outside the province of fiq $h$.

According to Tariq Ramadan, fiqh merely adapts to prevailing realities (which it takes for granted), an approach which has no doubt enabled "millions of Muslims ... to remain faithful as possible to their religion" (fiqh al-aqaliyyat or jurisprudence of minorities as an example) but is severely limited when it comes to offering a long-term vision to transform and change society. ${ }^{5}$

Take for instance, democracy. While democracy has been conventionally justified in figh on the ground of shura (consultation) as an indirect reference to democracy, albeit one with a Qur'anic basis, the richer and more direct discussions throughout Islamic intellectual history were carried out by the philosophers, who called democracy al-madinah al-jama'iyyah or siyasat-i jama'at in Arabic or Persian respectively, in both cases literally meaning "the city of the community". In the works of such philosophers as Abu Nasr al-Farabi (870-950), Ibn Rushd (1126-1198) and Nasir al-Din al-Tusi (1201-1274), the formation of the various types of "cities" is the result of different combinations of individuals with different needs, such as for the common pursuit of honour (timocracy), wealth (oligarchy) or freedom (democracy). Nasir al-Din al-Tusi 
counts democracy among the cities that fall short of the ideal Virtuous City, yet concedes that, owing to the rich diversity therein, "it is easier and closer to feasibility to create Virtuous Cities" out of democracies than other types of cities. ${ }^{6}$ Such insight goes well beyond a limited conception of democracy as mere consultative process but instead envisions strategies for the attainment of happiness ( $\left.s a^{\prime} a d a h\right)$ and consequently, perfection of the soul. Yet such resources are to be found in politics, as an extension of ethics (akhlaq) and a branch of practical philosophy (hikmat-i 'amali), not fiqh, which thus makes the case for an understanding of constitutional law as an ethico-political discourse, and only secondarily as a legal one.

This is all the more plausible given that modern constitutional doctrines such as the rule of law, separation of powers and judicial independence developed out of political theories. This distinctive character of constitutional law is why the famous jurist John Austin denied it legal status, claiming that "constitutional law is positive morality merely", and thus infringements of constitutional law are not called "illegal" but "unconstitutional". ${ }^{7}$ Similarly, Friedrich Hayek argued that constitutional law is law merely in the formal, not material sense, for it is not a law among laws but a "superstructure erected to secure the maintenance of the law". ${ }^{8}$ Hayek distinguished between rules of just conduct and rules of organisation, and claimed that constitutional law belongs to the latter: i.e., it maintains, indeed constitutes, the organisation itself (in this case, that political community which we call "state"). In cases of revolution resulting in the adoption of a new constitution, for example, while rules of just conduct, such as criminal law or property law, remain intact, constitutional law changes. And the nature of this change is what determines the direction of the nation as a whole.

Our retrieval of the ethico-political as the central domain of constitutional law calls for clarification on the nature of ethics and politics. If ethics is understood in the modern sense as "the systematic endeavour to understand moral concepts and justify moral principles and theories", then akhlaq does not fit this definition and hence cannot be conceived of as the equivalent of modern ethics. Al-Tusi's definition of akhlaq makes this clear: it is "a science concerned with how the human soul can acquire a disposition such that all its acts, proceeding from it by its will, may be fair and praiseworthy".

Thus "the subject matter of this science is the human soul"10, not moral principles and concepts. By anchoring ethics in the human soul, a community can be conceived as the macrocosmic extension and reflection of the human individual so that this collective entity does not evolve into a body that overrides its human members as, for example, when the individual is made subservient to "corporate values" and "corporate interests". Instead of organisations made to serve human ends, the matter becomes exactly reversed: human beings are 
made subservient to corporate ends. ${ }^{11}$ In other words, it humanises rather than corporatises the collectivity, making "corporate values" subordinate to human virtues.

\section{Conclusion and Recommendations}

Fiqh as it relates to constitutional law should be anchored to and developed with the over-arching ethical-political meta-narrative that functions as the constitutional ethic of the nation or community.

- The said constitutional ethic should be vigilantly conscious and cognisant of both internal changes within the polity and external transformations that require adjustments to the constitutional framework, particularly when there are constitutional hindrances to the formation of new alliances, partnerships and other forms of organisation.

- At the same time, a common constitutional framework between nations should be developed to address specific areas of cooperation especially with regard to institutional arrangements that may materialise into transnational entities. The starting point should always be the plural heritage of the community which is shared outside its national borders.

- The imperative to adapt to prevailing realities should be balanced with a proactive and dynamic initiative towards making positive changes and transformations.

\section{Notes}

* Tengku Ahmad Hazri, an Analyst at IAIS-Malaysia, he obtained his LLB (Hons) from the University of London, then served at the International Movement for a Just World (JUST). He is pursuing post-graduate studies in Islamic thought at ISTAC in Kuala Lumpur; and is an active blogger on philosophical and contemporary issues, contributing his reviews to the Malaysian press, Amazon.com and other websites.

1. Mohammad Hashim Kamali, "Constitutionalism and Democracy: an Islamic Perspective", ICR, Vol. 2 No. 1 (October 2010), 18-45 at 21. Kamali also cites 'Abd al-Razzaq al-Sanhuri, 'Abd alHamid al-Mutawalli and Hassan al-Turabi who made claims to the same effect.

2. Noah Feldman, The Fall and Rise of the Islamic State (Princeton and Oxford: Princeton University Press, 2012), 71.

3. Mohammad Hashim Kamali, Citizenship and Accountability of Government: an Islamic Perspective (Cambridge: Islamic Texts Society, 2011), 127-134. Among others, Kamali discusses Abu'l A'la Mawdudi's condemnation of nationalism as tribal fanaticism ('asabiyyah).

4. 'An endless debate over religion's role', The Economist, October $6^{\text {th }} 2012,58$

5. Tariq Ramadan, Radical Reform: Islamic Ethics and Liberation (Oxford: Oxford University Press, 2009), 30-34. Ramadan distinguished between "adaptation reform" and "transformation reform", arguing that fiqh needs to move from the former to the latter.

6. Nasir ad-Din Tusi, Akhlaq-i Nasiri (translated from the Persian as Nasirean Ethics by G.M. Wickens) (London: George Allen \& Unwin, 1964), 225.

7. John Austin, The Province of Jurisprudence Determined (Cambridge Texts in the History of 
Political Thought) (ed. Wilfrid E. Rumble) (Cambridge: Cambridge University Press, 1995), Lecture VI, 216.

8. Friedrich A. Hayek, Law, Legislation and Liberty, Volume 1: Rules and Order (Chicago: The University of Chicago Press, 1973), 134.

9. Louis P. Pojman (ed.), Ethical Theory: Classical and Contemporary Readings (Canada: Wadsworth, 2002), 1.

10. Nasir ad-Din Tusi, Akhlaq-i Nasiri (translated from the Persian as Nasirean Ethics by G.M. Wickens) (London: George Allen \& Unwin, 1964), 35 (emphasis added).

11. The use of the word "corporate" here is significant because the state is in a sense a corporate body, i.e., a type of corporation. In fact, the first modern state was the Catholic Church after the Gregorian Reforms (or Papal Revolution) in the 11th and 12th centuries during which the Church became a corporate entity by using the law of corporations modelled after Roman law to establish the Church as a legal personality, with the right to make transactions and own property, among others. The corporation law even functioned as the "constitutional law" of the Church. For discussion, see

Harold J. Berman, Law and Revolution: The Formation of the Western Legal Tradition (Cambridge, Massachusetts: Harvard University Press, 1985), 113-115, 205-224. 